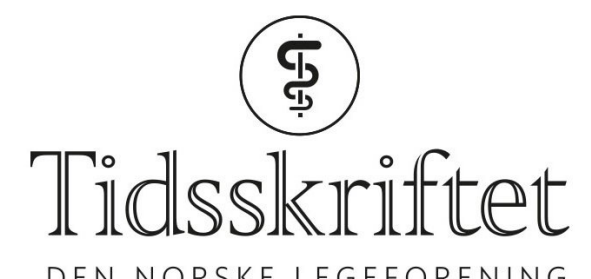

DEN NORSKE LEGEFORENING

\title{
Genetisk utredning ved amyotrofisk lateral sklerose
}

ORIGINALARTIKKEL

\section{OLA NAKKEN}

E-post: ola.nakken@medisin.uio.no Institutt for klinisk medisin

Universitetet i Oslo

og

Nevroklinikken

Akershus universitetssykehus

Han har bidratt med utforming/design, datainnsamling, litteratursøk, tolkning av data og utarbeiding av selve manuset.

Ola Nakken er spesialist i nevrologi, klinisk stipendiat og overlege.

Forfatter har fylt ut ICMJE-skjemaet og oppgir ingen interessekonflikter.

\section{LILLIAN SøRUM}

Urologisk avdeling

Akershus universitetssykehus

Hun har bidratt med datainnsamling, tolkning av data og revisjon av manus.

Lillian Sørum er lege i spesialisering.

Forfatter har fylt ut ICMJE-skjemaet og oppgir ingen interessekonflikter.

\section{TRYGVE HOLMØY}

\section{ALS-klinikken}

Akershus universitetssykehus

og

Institutt for klinisk medisin

Universitetet i Oslo

Han har bidratt med idé, utforming/design, litteratursøk og utarbeiding og revisjon av manus.

Trygve Holmøy er professor i nevrologi, overlege og leder av ALS-klinikken ved Akershus universitetssykehus.

Forfatter har fylt ut ICMJE-skjemaet og oppgir ingen interessekonflikter.

Ola Nakken og Lillian Sørum har bidratt i like stor grad til manuskriptet.

\section{BAKGRUNN}

I $70 \%$ av tilfellene med familiær amyotrofisk lateral sklerose (ALS) og $10 \%$ av de med sporadisk form kan genetisk utredning gi en diagnose stilt på molekylært nivå. Molekylært stilt diagnose kan åpne for deltagelse i kliniske studier, men endrer ellers ikke behandlingen. Betydningen for slektningers sykdomsrisiko kan være usikker, og den psykologiske belastningen stor. Utredningen reiser vanskelige etiske spørsmål. Vi har undersøkt om klinisk praksis samsvarer med internasjonale anbefalinger, som fraråder genetisk utredning ved typisk sporadisk variant. 
Vi gjennomgikk journalene til alle pasienter med amyotrofisk lateral sklerose ved Akershus universitetssykehus i perioden 2004-14.

\section{RESULTATER}

Av 115 pasienter manglet familieanamnese i journalen hos 44 (38\%). Diagnostisk gentesting ble utført hos fem av syv pasienter med familiær amyotrofisk lateral sklerose og tre med sporadisk type, enten fordi sykdomsforløpet var atypisk eller etter anbefaling fra spesialist i medisinsk genetikk som utredet pasientens slektninger. Ytterligere 11 pasienter med påvist mutasjon var henvist fra andre sykehus. Av disse ble fem enten rekruttert til ekstern behandlingsstudie eller senere inkludert i forskningsprosjekt på sykdomsmekanismer tilknyttet avdelingen. Analysene omfattet nesten utelukkende SOD1-genet.

\section{FORTOLKNING}

Studien avdekket at praksis var restriktiv i tråd med anbefalingene og at nyoppdagede ALSgener sjelden ble analysert. Pasientautonomi og krav om molekylært stilt diagnose for å delta i studier utfordrer en slik praksis.

Om lag 150 personer får amyotrofisk lateral sklerose (ALS) i Norge hvert år, og antallet er økende (1). Tradisjonelt har tilstanden blitt oppfattet som en rent motorisk sykdom karakterisert av progredierende pareser, men inntil halvparten utvikler også tegn til kognitiv svikt med atferds- og personlighetsforstyrrelser. En mindre andel utvikler frontotemporal demens (2). Pasientene dør vanligvis av respirasjonssvikt 2-3 år etter diagnosetidspunktet (3).

Amyotrofisk lateral sklerose deles gjerne inn i en sporadisk form uten andre kjente tilfeller $\mathrm{i}$ slekten ( $90-95 \%$ av tilfellene) og en familiær form (5-10\% av tilfellene). Arvegangen ved sistnevnte er som oftest autosomalt dominant med ufullstendig og ofte ukjent penetrans. Siden oppdagelsen av mutasjoner i SOD1-genet i 1993 har det blitt påvist patogene mutasjoner i om lag 30 ulike gener ved familiær amyotrofisk lateral sklerose (3). Til sammen forklarer disse rundt 6o-8o \% av disse tilfellene (4). Slike mutasjoner finnes imidlertid også hos om lag $10 \%$ av pasienter med sporadisk amyotrofisk lateral sklerose og hos betydelig flere som også har frontotemporal demens (5). Den vanligste årsaken til både arvelig amyotrofisk lateral sklerose og frontotemporal demens er $ø \mathrm{kt}$ antall repetisjoner av nukleotidene GGGGCC i Cgorf72-genet (6). Testing av denne mutasjonen utføres ikke i Norge. Hyppigheten er derfor ikke kjent, men i andre land er den rapportert hos om lag $40 \%$ ved familiær amyotrofisk lateral sklerose, $10 \%$ ved sporadisk amyotrofisk lateral sklerose og $20 \%$ ved frontotemporal demens $(7,8)$.

Det finnes per i dag ingen spesifikk terapi for noen av de genetiske variantene av amyotrofisk lateral sklerose. Ved den sporadiske formen er betydningen av et positivt funn for sykdomsrisiko hos slektninger usikker og kan utgjøre en stor tilleggsbelastning både for pasient og pårørende. Både den europeiske nevrologiforeningen (EFNS) og den europeiske interessegruppen for amyotrofisk lateral sklerose (ENCALS) frarådet derfor i 2004, 2007 og 2012 genetisk testing av pasienter med sporadisk variant, men åpnet for at testing kan utføres hos personer med familiær type eller atypiske kliniske funn der testing kan bidra til å avklare diagnosen (9-11). I Norge finnes det ikke offisielle faglige retningslinjer for utredning og oppfølging av amyotrofisk lateral sklerose. Anbefalinger i norsk elektronisk legemiddelhåndbok (Nevro-NEL) samsvarer med anbefalingene fra den europeiske nevrologiforeningen. Formålet med denne studien var å undersøke om praksis for genetisk 
utredning av pasienter med amyotrofisk lateral sklerose følger nasjonale og internasjonale anbefalinger.

\section{Metode}

Vi søkte elektronisk pasientjournal (EPJ) ved Akershus universitetssykehus for pasienter kodet G12.2 i henhold til ICD-10 (den internasjonale statistiske klassifikasjonen av sykdommer og beslektede helseproblemer) i perioden 31.12.2004-31.12.2014. G12.2 omfatter motornevronsykdommer, der amyotrofisk lateral sklerose er den desidert største pasientgruppen. Unntatt fra G12.2 er medfødte og arvelige varianter av spinale muskelatrofier. Vi vurderte hvorvidt diagnosen var korrekt samt om pasienten var primært utredet og fulgt ved Akershus universitetssykehus. Fra journalen innhentet vi så opplysninger om kjønn, alder, familieanamnese, genetisk testing og genetisk veiledning. Data ble oppbevart på sikker forskningsserver med avidentifiserte kliniske data separert fra koblingsnøkkelen.

Det er ingen klar konsensus for hva som skal defineres som familiær amyotrofisk lateral sklerose (12). I tråd med nyere anbefalinger basert på klinisk og etiologisk overlapp, ble pasienter med minst én første- eller annengradsslektning med amyotrofisk lateral sklerose eller frontotemporal demens klassifisert som familiær amyotrofisk lateral sklerose $(13,14)$.

Studien ble godkjent av personvernombudet ved Akershus universitetssykehus som en kvalitetsstudie. Det ble derfor ikke søkt godkjenning fra regional komité for medisinsk og helsefaglig forskningsetikk.

\section{Resultater}

Resultatene av journalgjennomgangen er vist i figur 1. Etter eksklusjon av ni feilkodede pasienter ble totalt 126 pasienter med amyotrofisk lateral sklerose vurdert ved Akershus universitetssykehus i studieperioden. Av disse ble 115 primært utredet og fulgt opp ved Akershus universitetssykehus, mens 11 pasienter med familiær type der det allerede var påvist ALS-assosierte mutasjoner, var henvist fra andre sykehus. 


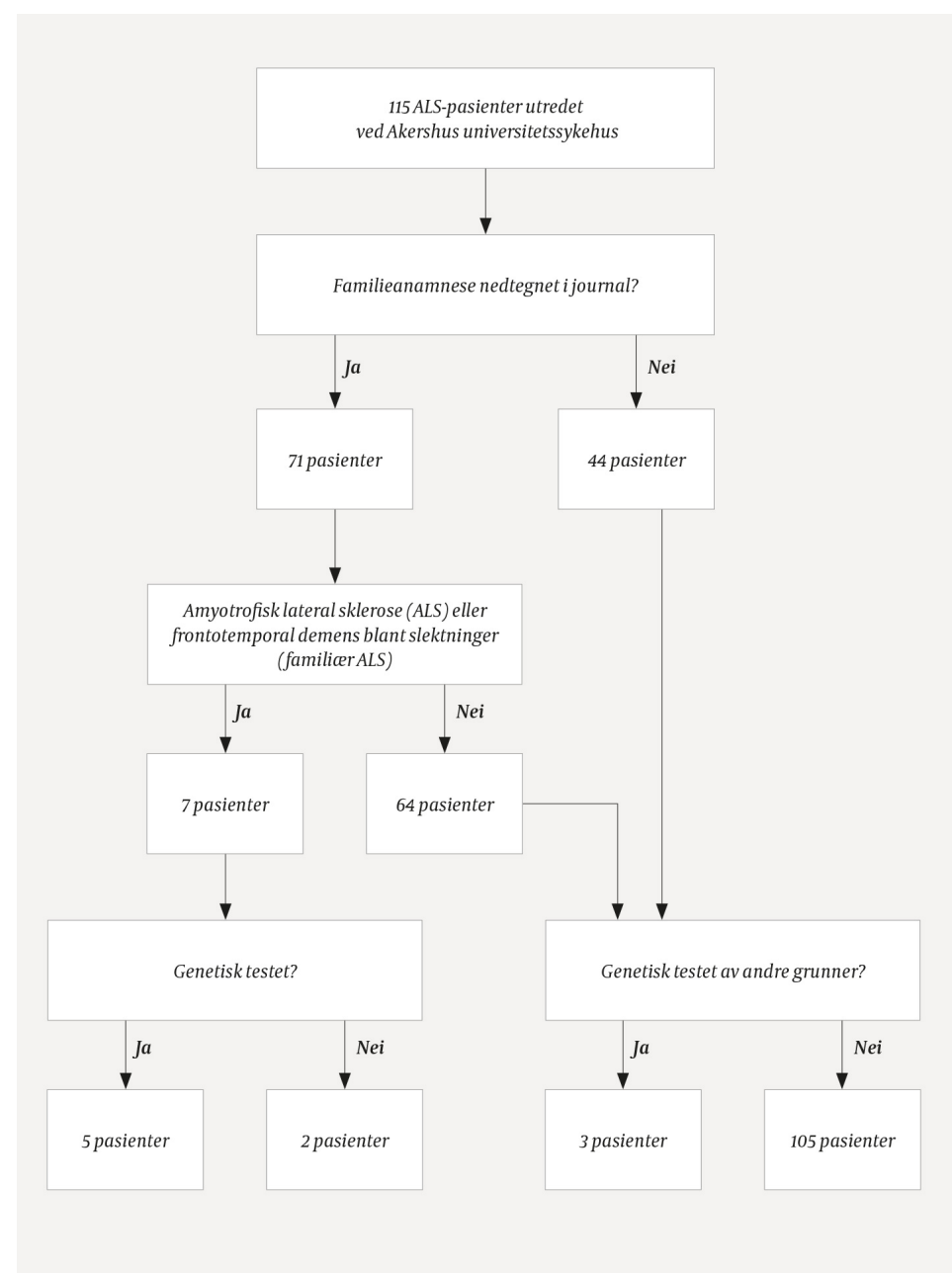

Figur 1 Genetisk utredning av pasienter med amyotrofisk lateral sklerose utredet ved Akershus universitetssykehus i perioden 2004-14

Ved gjennomgang av journalene fant vi at familieanamnesen var dokumentert hos 71 (62\%) av de 115 pasientene som hadde blitt utredet ved Akershus universitetssykehus. Av de 71 hadde syv (10\%) nære slektninger med amyotrofisk lateral sklerose eller frontotemporal demens forenlig med familiær amyotrofisk lateral sklerose. Blant disse ble det utført genetisk analyse hos fem pasienter. Det er ikke dokumentert i journalen hvorvidt genetisk utredning ble vurdert hos de øvrige to pasientene med familiær variant.

Det ble sendt blodprøve til diagnostisk genetisk analyse hos tre pasienter med sporadisk amyotrofisk lateral sklerose. Hos disse var unders $\emptyset$ kelsen begrunnet med atypisk forl $\emptyset$, annen alvorlig nevrologisk sykdom (ikke motornevronsykdom eller frontototemporal demens) i nær slekt, eller den ble utført etter anmodning fra spesialist i medisinsk genetikk i forbindelse med pårørendes ønske om prediktiv testing.

Genetisk analyse ble nesten utelukkende utført på SOD1-genet, og hovedsakelig i siste halvdel av studieperioden. Med unntak av en pasient som fikk påvist heterozygot mutasjon uten sikker betydning, ble alle pasienter som fikk påvist ALS-relatert mutasjon tilbudt genetisk veiledning. I samråd med pasienten ble også pårørende informert og tilbudt genetisk veiledning. Ingen andre pasienter fikk tilbud om genetisk veiledning. Hos de to pasientene med antatt familiær amyotrofisk lateral sklerose som ikke fikk utført genetisk analyse, ble heller ikke genetisk veiledning nevnt i journalen.

Mot slutten av studieperioden fikk pasienter med påvist ALS-mutasjon tilbud om å delta i forskningsprosjekter. Fem donerte hudbiopsi for generering av induserbare pluripotente stamceller. Det ble også formidlet kontakt som muliggjorde deltagelse i en behandlingsstudie i utlandet. 


\section{Diskusjon}

Våre funn viser en gjennomgående restriktiv praksis for genetisk utredning ved amyotrofisk lateral sklerose. Kun tre pasienter med sporadisk variant fikk utført diagnostisk gentesting, og dette var hos alle begrunnet i journalen. Med unntak av testing av én pasient med sporadisk variant initiert av spesialist i medisinsk genetikk ut fra pårørendes ønske om prediktiv testing, var vår praksis i tråd med europeiske anbefalinger som spesifikt har frarådet genetisk testing ved typisk sporadisk type (9-11).

To av syv pasienter med familiær variant fikk ikke tilbud om genetisk testing eller genetisk veiledning. Siden spørsmålet ikke var drøftet i journalen, kjenner vi ikke årsakene til at genetisk testing ikke ble utført. Fravær av eksplisitt begrunnelse kan gjenspeile lav bevissthet rundt betydningen av arvelighet, eller usikkerhet rundt tilgangen på genetisk testing og veiledning. En slik antagelse støttes av en studie fra 20 land som viser at nevrologer med stor erfaring med amyotrofisk lateral sklerose oftere tilbyr genetisk utredning enn mindre erfarne kolleger (14). En annen forklaring kan være et bevisst eller ubevisst $\emptyset$ nske om å ikke bidra til å øke bekymringen for at slektninger også skal utvikle sykdommen. At familieanamnesen ikke var journalført hos nærmere $40 \%$ av pasientene, er forenlig med begge disse forklaringene.

Den lave bruken av gentesting kan også gjenspeile et begrenset tilbud til slike analyser $\mathrm{i}$ Norge. En rekke ALS-relaterte gener, inkludert C9orf72 som er den klart hyppigste genetiske årsaken til amyotrofisk lateral sklerose, ble oppdaget i løpet av studieperioden. Oslo universitetssykehus analyserte imidlertid gjennom hele studieperioden kun SOD1, og analyserer fortsatt ikke andre ALS-relaterte gener. Mutasjoner i SOD1 forklarer kun en liten del av familiær amyotrofisk lateral sklerose (ca. 20 \%), og analyse av kun dette genet regnes derfor ikke som tilstrekkelig utredning verken ved familiær variant eller atypiske forløpsformer av sporadisk type $(14,15)$. Den genetiske epidemiologien er ikke kartlagt i Norge, men ved å analysere C9orf72, FUS og TARDBP i tillegg til SOD1 vil man sannsynligvis kunne påvise den genetiske bakgrunnen til om lag to tredeler av de med familiær amyotrofisk lateral sklerose og $10 \%$ av de med sporadisk type (14, 16).

Oppdagelsen av nye ALS-relaterte gener kan føre til at både pasienter, pårørende og leger oppfatter utredningen som mer meningsfull, ettersom den i større grad faktisk kan påvise eller utelukke genetisk årsak til sykdommen (17). Sykehuset i Telemark analyserer nå foruten SOD1 17 andre ALS-relaterte gener samt en rekke gener som er assosiert med andre motornevronsykdommer, men tester foreløpig ikke for Cgorf72 (Helle Høyer, personlig meddelelse). Hovedargumentene for ikke å tilby genetisk testing ved sporadisk variant er at dette utfordrer hensynet til pårørende og pasientens rett til ikke å vite (15). Funn av en ALSmutasjon hos en ALS-syk har vidtrekkende konsekvenser for friske slektninger. Disse må forholde seg til at deres risiko for å utvikle sykdommen kan være betydelig økt og må ta stilling til om de ønsker prediktiv testing, som etter norsk lov krever genetisk veiledning. Usikkerheten rundt betydningen av både positive og negative funn gjør at denne verken kan gi friske slektninger et tydelig beslutningsgrunnlag før testing eller sikker avklaring av egen risiko når testresultatet foreligger (18). Dette skiller seg fra Huntingtons sykdom, der en negativ gentest utelukker sykdommen og et positivt funn også gir viktig informasjon om forventet prognose (19).

Den relativt restriktive praksisen med å forbeholde genetisk testing til pasienter med familiær type eller atypisk forløp har i de senere år blitt utfordret (20), blant annet fordi den frarøver pasienten muligheten til å utforske årsaken til sykdommen (15). Dessuten gjør hyppige funn av ALS-mutasjoner hos pasienter med tilsynelatende sporadisk form grenseoppgangen mot familiær form mer arbitrær enn tidligere antatt (20, 21). Den relativt høye sannsynligheten for å oppdage en ALS-relatert mutasjon brukes således som argument både for en restriktiv og en liberal praksis for gentesting ved sporadisk amyotrofisk lateral sklerose $(11,17,20)$. Ø kt innsikt i sykdommens genetiske årsaker er viktig for å forstå sykdomsmekanismene, og trolig vil mange fremtidige behandlingsstudier kreve molekylær utredning (22). Vår erfaring er at mange pasienter ønsker å delta i kliniske studier. Det er 
derfor sannsynlig at flere pasienter vil etterspørre molekylær utredning. Ettersom det vil bli mulig å teste for flere gener, øker også sannsynligheten for påvisning av genvarianter med usikker sykdomsassosiasjon og betydning for slektningers risiko. Da vil det også bli et betydelig større behov for genetisk veiledning.

Mange pasienter ønsker å vite årsaken til egen sykdom og risikoen for at den videreføres i slekten (18). I en spørreundersøkelse blant 5591 amerikanske ALS-pasienter svarte $83 \%$ av respondentene at genetisk testing burde tilbys alle pasienter med sykdommen, og $73 \%$ mente at fordelene oppveiet ulempene (23). De som hadde gjennomgått genetisk testing, rapporterte overveiende positive erfaringer, uavhengig av sykdomsform (sporadisk eller familiær) og av hvorvidt de hadde fått genetisk veiledning (24). Responsraten i denne undersøkelsen var lav (8\%), og generaliserbarheten er derfor usikker. Diskrepansen mellom de positive tilbakemeldingene og den restriktive praksisen som gjenspeiles i våre funn og i europeiske anbefalinger, reiser likevel spørsmålet om nevrologer har en paternalistisk og overbeskyttende tilnærming, som kanskje også reflekterer eget ubehag ved å gå inn i disse spørsmålene.

\section{Konklusjon}

Vår studie avdekket en restriktiv bruk av gentesting ved amyotrofisk lateral sklerose. Med unntak av at familieanamnesen ikke var nedtegnet hos nesten $40 \%$ av pasientene, var bruken i tråd med europeiske anbefalinger. Analysen omfattet ikke nyoppdagede og påvisbare ALS-assosierte gener som kunne ha økt den diagnostiske treffsikkerheten (17). Etablert genetisk diagnose kan åpne for deltagelse i behandlingsstudier og studier av sykdomsmekanismer (25), også ved mutasjoner i SOD1 som ser ut til å forekomme relativt hyppig i Norge (26). Flere pasienter med påvist mutasjon har donert hudbiopsi til generering av induserbare pluripotente stamceller og studier av sykdomsmekanismer, eller fått tilbud om å delta i behandlingsstudier i utlandet. Repertoaret av genetiske analyser bør derfor utvides i tråd med internasjonal standard.

\section{HOVEDBUDSKAP}

Fagmiljøer har til nå kun anbefalt genetisk testing av ALS-pasienter med positiv slektsanamnese eller atypiske kliniske funn

Praksis ved Akershus universitetssykehus var i tråd med anbefalingene

Genetisk testing omfattet nesten utelukkende SOD1-genet, på tross av at en hyppigere sykdomsassosiert mutasjon i Cgorf72-genet ble oppdaget i løpet av studieperioden

$\emptyset$ kt vekt på pasientautonomi og krav om molekylært stilt diagnose for å delta i behandlingsstudier kan føre til liberalisert praksis for genetisk testing hos pasienter uten positiv slektsanamnese

\section{LITTERATUR:}

1. Nakken O, Lindstrøm JC, Tysnes OB et al. Mortality trends of amyotrophic lateral sclerosis in Norway 1951-2014: an age-period-cohort study. J Neurol 2016; 263: 2378 - 85. [PubMed][CrossRef]

2. Strong MJ, Abrahams S, Goldstein LH et al. Amyotrophic lateral sclerosis - frontotemporal spectrum disorder (ALS-FTSD): Revised diagnostic criteria. Amyotroph Lateral Scler Frontotemporal Degener 2017; 18: 153-74. [PubMed][CrossRef]

3. Brown RH, Al-Chalabi A. Amyotrophic lateral sclerosis. N Engl J Med 2017; 377: 162 - 72.

[PubMed][CrossRef]

4. van Es MA, Hardiman O, Chio A et al. Amyotrophic lateral sclerosis. Lancet 2017; 390: 2084 - 98.

[PubMed][CrossRef] 
5. Dols-Icardo O, García-Redondo A, Rojas-García R et al. Analysis of known amyotrophic lateral sclerosis and frontotemporal dementia genes reveals a substantial genetic burden in patients manifesting both diseases not carrying the C9orf72 expansion mutation. J Neurol Neurosurg Psychiatry 2018; 89:162 - 8. [PubMed][CrossRef]

6. Renton AE, Majounie E, Waite A et al. A hexanucleotide repeat expansion in C9ORF72 is the cause of chromosome 9p21-linked ALS-FTD. Neuron 2011; 72: 257 - 68. [PubMed][CrossRef]

7. Smith BN, Newhouse S, Shatunov A et al. The C9ORF72 expansion mutation is a common cause of ALS+/-FTD in Europe and has a single founder. Eur J Hum Genet 2013; 21: 102 - 8. [PubMed][CrossRef]

8. Gjerde KV, Tysnes OB. Genetisk sammenheng mellom amyotrofisk lateral sklerose og frontotemporal demens. Tidsskr Nor Legeforen 2014; 134:302 - 6. [PubMed][CrossRef]

9. Andersen PM, Borasio GD, Dengler R et al. EFNS task force on management of amyotrophic lateral sclerosis: guidelines for diagnosing and clinical care of patients and relatives. Eur J Neurol 2005; 12: 921 -38. [PubMed][CrossRef]

10. Andersen PM, Borasio GD, Dengler R et al. Good practice in the management of amyotrophic lateral sclerosis: clinical guidelines. An evidence-based review with good practice points. Amyotroph Lateral Scler 2007; 8: 195 - 213. [PubMed][CrossRef]

11. Andersen PM, Abrahams S, Borasio GD et al. EFNS guidelines on the clinical management of amyotrophic lateral sclerosis (MALS)-revised report of an EFNS task force. Eur J Neurol 2012; 19:36o 75. [PubMed][CrossRef]

12. Byrne S, Elamin M, Bede P et al. Absence of consensus in diagnostic criteria for familial neurodegenerative diseases. J Neurol Neurosurg Psychiatry 2012; 83:365 - 7. [PubMed][CrossRef]

13. Byrne S, Bede P, Elamin M et al. Proposed criteria for familial amyotrophic lateral sclerosis. Amyotroph Lateral Scler 2011; 12: 157 - 9. [PubMed][CrossRef]

14. Vajda A, McLaughlin RL, Heverin M et al. Genetic testing in ALS: A survey of current practices. Neurology 2017; 88: 991 - 9. [PubMed][CrossRef]

15. Turner MR, Al-Chalabi A, Chio A et al. Genetic screening in sporadic ALS and FTD. J Neurol Neurosurg Psychiatry 2017; 88:1042 - 4. [PubMed][CrossRef]

16. Chiò A, Battistini S, Calvo A et al. Genetic counselling in ALS: facts, uncertainties and clinical suggestions. J Neurol Neurosurg Psychiatry 2014; 85: 478 - 85. [PubMed][CrossRef]

17. Roggenbuck J, Quick A, Kolb SJ. Genetic testing and genetic counseling for amyotrophic lateral sclerosis: an update for clinicians. Genet Med 2017; 19:267 - 74. [PubMed][CrossRef]

18. Hogden A, Crook A. Patient-centered decision making in amyotrophic lateral sclerosis: where are we? Neurodegener Dis Manag 2017; 7:377 - 86. [PubMed][CrossRef]

19. Quaid KA. Genetic Testing for Huntington Disease. I: Andrew SF, Karen EA, red. Huntington Disease. Elsevier Science Publishing Co Inc, 2017: 113-26. Volum 144 i serien: Handbook of Clinical Neurology.

20. Al-Chalabi A. Perspective: don't keep it in the family. Nature 2017; 550: S112. [PubMed][CrossRef]

21. Talbot K. Familial versus sporadic amyotrophic lateral sclerosis-a false dichotomy? Brain 2011; 134: 3429-31. [PubMed][CrossRef]

22. Scott A. Drug therapy: on the treatment trail for ALS. Nature 2017; 550: S120 - 1. [PubMed][CrossRef]

23. Wagner KN, Nagaraja H, Allain DC et al. Patients with amyotrophic lateral sclerosis have high interest in and limited access to genetic testing. J Genet Couns 2017; 26: 604 - 11. [PubMed][CrossRef]

24. Wagner KN, Nagaraja HN, Allain DC et al. Patients with sporadic and familial amyotrophic lateral sclerosis found value in genetic testing. Mol Genet Genomic Med 2018; 6: 224 - 9. [PubMed][CrossRef] 25. Chia R, Chiò A, Traynor BJ. Novel genes associated with amyotrophic lateral sclerosis: diagnostic and clinical implications. Lancet Neurol 2018; 17: 94 - 102. [PubMed][CrossRef]

26. Lange DJ, Shahbazi M, Silani V et al. Pyrimethamine significantly lowers cerebrospinal fluid Cu/Zn superoxide dismutase in amyotrophic lateral sclerosis patients with SOD1 mutations. Ann Neurol 2017; 81: 837-48. [PubMed][CrossRef] 
Publisert:3. september 2018. Tidsskr Nor Legeforen. DOI: 10.4045/tidsskr.18.0193

Mottatt 23.2.2018, første revisjon innsendt 11.5.2018, godkjent 22.5.2018.

(C) Tidsskrift for Den norske legeforening 2020. Lastet ned fra tidsskriftet.no 